\title{
Firm Size, Audit Firm Size, Profitability, Solvability, and Public Ownership Influences on Audit Delay
}

\author{
Katherine Handayani Ubwarin ${ }^{1}$, Christina Tri Setyorini ${ }^{2}$, Icuk Rangga Bawono ${ }^{3 *}$ \\ ${ }^{123}$ Accounting Department, Jenderal Soedirman University, Indonesia \\ 1ubwarin@gmail.com, 2ninataufikh@yahoo.com, ${ }^{3}$ cukycutes@yahoo.com \\ *corresponding author
}

\begin{abstract}
This study aims to measure company size, company audit size, profitability, solvency and public ownership toward audit delay. It is an explanatory study with a quantitative approach. It selects transportation industries listed in Indonesia Stock Exchange (BEI) on period of 2008-2015 as population. It took 64 samples from public companies using purposive sampling method. Data were analyzed using Multiple Regression Analysis that include descriptive statistics, classical assumption test, and hypothesis testing (multiple linear regression, simultaneous test and partial test). The results of this study proved to be useful and efficient. Based on test results in this study, it can be concluded that firm size and audit firm size have an effect on audit delay. Meanwhile, profitability, Solvability, and public ownership have no effect to audit delay.
\end{abstract}

Keywords: audit delay, audit firm size, firm characteristic

\section{Pengaruh Ukuran Perusahaan, Ukuran Kantor Audit, Profitabilitas, Solvability, dan Kepemilikan Publik terhadap Audit Delay}

\begin{abstract}
Abstrak
Penelitian ini bertujuan untuk mengukur ukuran perusahaan, ukuran audit perusahaan, profitabilitas, solvabilitas dan kepemilikan publik terhadap penundaan audit. Jenis penelitian ini adalah penelitian eksplanatori dengan pendekatan kuantitatif. Penelitian ini memilih industri transportasi yang terdaftar di Bursa Efek Indonesia (BEI) pada periode 2008-2015 sebagai populasi. Penelitian ini mengambil 64 sampel dari perusahaan publik dengan menggunakan metode purposive sampling. Data dianalisis dengan menggunakan Analisis Regresi Berganda yang mencakup statistik deskriptif, uji asumsi klasik, dan pengujian hipotesis (regresi linier berganda, uji simultan dan uji parsial). Hasil penelitian ini terbukti bermanfaat dan efisien. Berdasarkan hasil pengujian dalam penelitian ini, dapat disimpulkan bahwa ukuran perusahaan dan ukuran kantor audit berpengaruh terhadap audit delay. Sementara itu profitabilitas, Solvabilitas, dan kepemilikan publik tidak berpengaruh terhadap audit delay.
\end{abstract}

Kata kunci: audit delay, karakteristik perusahaan, ukuran kantor audit

\section{INTRODUCTION}

Financial statements for investors are used to consider the firm's prospects before they put their investments. For creditors, financial statements are used to measure a firm's ability in completing a loan before they lend their capital. Based on a regulation issued by (Otoritas Jasa Keuangan, n.d.), a financial statement of a public firm should be audited. It must be fulfilled to settle their obligation restricted by the laws in the capital market which set regulations regarding the annual audited financial statement. On a financial statement of a firm published in the Capital Market Supervisory Agency (BAPEPAM), they must attach an audited financial statement by a public accountant. A professional auditor must be on time to submit the audit report. The citation from (Sahamok, n.d.) website explains that 
there are recently 539 public firms listed in (Indonesia Stock Exchange, n.d.), as a result, there is a demand for audited financial statements by a public accountant.

Each country has its regulation dealing with the deadline of delays on publication financial statements. The regulations become obstacles to several firms to complete their audit reports of financial statements on time. Timeliness is a disclosure of the relevant detail in the financial statements if the information reported on time for almost all users to make a decision. A financial statement is said to be irrelevant if a delay occurs in reporting. In Indonesia, $B A P E P A M$ and IDX have set the regulation that the audited annual financial statement must be done in 90 days of the period. They also set public firms to submit the audited financial statement report to BAPEPAM and IDX to be published. These regulations can also be a guidance for auditors in their assignments with 90 days or 3 months for a minimum deadline of an audit. If a company breaks these regulations, it will get punishment. However, not all firms can finish their tasks on time, because the auditors need a long time to collect the competence evidence that can support the audit opinion.

Several firms listed on IDX are often reported of their delay of financial statement submission. The research in (Hernawati \& Rahayu, 2014) said that PT. Berlian Laju Tanker Tbk (BLTA) from a shipping sector committed to audit delay from 2008 until 2012. This occurred because of the high bond liability of up to $\mathrm{Rp} 22$ billion that gave side effects for BLTA to restructure the liability and for external auditor parties to do a full appraisal for its audit risk. There were also 24 emitents in 2019 receiving administrative punishment from IDX authorities because they didn't submit their audited financial report (Ayuningtyas, 2019). As a consequence, they received the written warning and additional fines amounted to IDR 150 million if in 61th until 90th of days from the deadline for submitting its financial statement they still have not completed their obligation as spoken in the regulation of II.6.2. and II.6.3. about delay in submitting a financial statement (Ikatan Akuntansi Indonesia (IAI), 2007). Meanwhile, in 2020 due to extraordinary event covid-19, to reduce the same cases, Financial Services Authority (OJK) extended the deadline for sending financial statements to May $31^{\text {st }}$ and annual reports to June $30^{\text {th }}$, 2020 .

The agency theory is used in this study to explain agency relationship as a contract between the agent (manager) and principal (owner) where the principal delegate half of their authority to the agent for a firm's activities and authority to make a decision (Jensen \& Meckling, 1976). From this authority, the agent will get more information than the principal (Eisenhardt, 1989). Angruningrum and Wirakusuma (Angruningrum \& Wirakusuma, 2013) explain that sometimes principals and agents have different interests in a contract. This can lead to conflicts of interest. The principals have an expectation to get high profitability quickly for their investment. Meanwhile, the agents are likely to pursue their self-interest which accommodate high compensation for running a business. To minimize conflicts, the principals and the agents agreed to collaborate with the third parties as auditors to the financial statement. This audit service has a purpose to determine compatibility between the statement and the criteria, and to disclose the result to 
interested users. Auditing from public accountant insight is the objective examination on a firm's financial statement, that has a purpose to determine whether the financial statement is presented fairly in material terms, show statement in changes of financial position and result of firm's sacrifice (Mulyadi, 2012).

The other theory that is relevant to explain about audit delay is signaling theory. It argues that the firm manager has more information about the firm and also is compelled to disclose the information for the potential investors in order to increase the shares price, while the shareholders have a lack of information of the firm (Ross, 1977). The signal will be given by accounting information disclosure such as financial statement reporting. This information is a signal about good or bad news that can influence the firm's shares price. The main benefits from this theory are the accuracy and timeliness on disclosure of financial statement to the public that can benefit as useful information. It also can be used by the investor to make a decision in the future (Divianto, 2011).

The research studies of audit delay have been examined in some of countries such as Turkey (Turel, 2010), Kuwait (Al-Ghanem \& Hegazy, 2011), Nigeria (Dabor \& Mohammed, 2015), Jordan (Alkhatib \& Qais, 2012), Croatia (Vuko \& Marko, 2014), Malaysia (Hashim \& Rahman, 2011), and also Indonesia. Turel (Turel, 2010) conducted an analysis on audit delay of 319 firms listed in Istanbul Stock Exchange on December $31^{\text {th }}$ 2007. There are several factors that affect audit delay. Firm size, audit firm size, profitability, solvability, and public ownership are several factors identified from the prior studies, in (Haryani \& Wiratmaja, 2014), (Ervilah \& Fachriyah, 2015), (Puspitasari \& Sari, 2012), (Aditya \& Anisykurlillah, 2014), (Hersugondo \& Kartika, 2013), (Rochmah \& Fachriyah, 2016), (Rachmawati, 2008), (Agatha, 2015), and (Badriyah, Raharjo, \& Andini, 2015).

The first factor influencing audit delay is firm size, as a tool of measurement on a firm that can be seen from total assets and its wealth. Dyer and McHugh (Dyer \& Hugh, 1975) states that a large firm will be more consistent on timeliness compared to a small firm. Ervilah \& Fachriyah (2015) explain that firm size has a significant relationship to effect on audit delay. The size of a firm can be seen from various viewpoints such as total employees, total assets or wealth, total sales, capital market value, etc. The larger company size would make audit delay longer than usual because audit field would be greater too (Agatha, 2015), since the larger companies have subsidiaries that require wider audit procedures. On other hand, research on (Haryani \& Wiratmaja, 2014) showed that only IFRS adoption and firm size which have no significant relationship in affecting a delay of audit. (Haryani \& Wiratmaja, 2014) also (Ervilah \& Fachriyah, 2015) used the variable of firm size but they have different results.

The second factor influencing audit delay is audit firm's size. The audit firm is an organization or group of public accountants which has license with the laws in providing professional service in public accountant practice. Quality of audit has impact to audit delay that has benefit to determine the credibility of financial statement. According to Puspitasari and Sari (2012), the size of an audit firm can be seen from the level of service quality that has effect on the time range of audit completion. Audit firm size could be 
influential when time to finish and audit can be seen from the result of an audit firm's quality. Ervilah and Fachriyah (2015) also explain that quality of auditor projected by audit firm size has a significant relationship effect on audit delay. In contrary, it is different from Aditya (2014) that explains that audit firm size variable has no significant relationship to delay of audit. He argued that almost all audit firms in Indonesia is proven to have good performance.

Profitability was used as a third factor that is indicated to affect audit delay in this study. Profitability is a tool used to analyze the performance of management. The level of profitability will describe a firm's earning (Agatha, 2015). Profitability also reflects the firm probability to get earning from investment. Potential investors and shareholders will pay close attention to profitability because it is related to shared prices and dividends they will receive. According to (Apriayanti \& Santosa, 2014), profitability is a relationship between revenues and expenses generated by utilizing the firm's assets in its production effectively. Manager would report gain profitability faster than the report of the losses profitability because its a good news for them. Hersugondo and Kartika (Hersugondo \& Kartika, 2013) researched the probability prediction of audit delay and the determiners and state that the level of profitability has no notable relationship with a delay of audit. The research explains that earning of a company has no difference in the audit process, but large earning makes auditor request a longer time than usual to set the report. In (Rochmah \& Fachriyah, 2016) research, they got a result that profitability affects audit delay. The firm that gets earning will certainly extend the audit delay because of huge earning. This makes an audit process takes longer than usual. Research of (Rachmawati, 2008) examined the research on manufacture firms and explain that there's no notable relationship between profitability and audit delay.

The fourth factor may affect delay submit of firm's audited financial report is solvability. Solvability can be linked to firm's ability to measure the ratio in paying off all long and short period of liabilities. According to (Puspitasari \& Sari, 2012), the unsolvable firm is a firm which has total liabilities more than total assets. A firm with high solvability ratio is a firm which has a high financial risk. It shows that the firm will most likely not be able to repay the liabilities. The high solvability of company also has a negative impact for the firm because it will delay the publication of financial statement. On the other hand, Agatha's research (Agatha, 2015) shows a different result that says that the solvability variable has a notable positive effect on the delay of an audit. The reason is that firms that have financial difficulties cannot publish their financial statements on time.

The last factor that may affect a firm to delay submission of audited financial report is public ownership. It is the share of going public firm owned by public. Percentage of public ownership can be seen at ICMD (Indonesia Capital Market Directory) (Haryani \& Wiratmaja, 2014). Fitria, Purnamasari, and Utomo (2015) explain that public ownership owned by public is $5 \%$ which is outside of management and does not have special relationship with the firm. Public share ownership can make impact on limited management's movement of firm because the market pressure will occurs with increasing performance of firm and also adherence to the regulations. The availability of shares 
owned by public will make the firm monitored by the external parties. The external parties can give influence to the firm via the mass media such as criticism or comment that belief from public's voice. As a result, the concentration of external party ownership can make changes in the management of firm of which at the beginning has run smoothly based on the firm's will become limited (Hasniar, 2012). This statement is in line with result of public ownership that has a significant relationship on the variable audit delay (Haryani \& Wiratmaja, 2014). The results show that only firm size, audit quality, and public ownership that don't have a significant relationship on the variable of audit delay (Badriyah et al., 2015).

Although there's several studies about audit delay on the firms listed in IDX, most empirical studies show inconsistent results in the last 10 years. Based on the explanation of phenomena and research gap, this research was motivated to analyze the factors that influence audit delay. It is a development and replication of the research study by (Hernawati \& Rahayu, 2014). This research is different from the previous one since it uses the independent variables of Firm Size, Audit Firm Size (Alkhatib \& Qais, 2012), Profitability (Hersugondo \& Kartika, 2013), Solvability (Agatha, 2015), and Public Ownership (Ervilah \& Fachriyah, 2015). Another difference here is that this research uses the financial statement data in the period of 2008-2015. The reason for using the year periods from 2008-2015 is that it emphasizes more on comparability of audited financial statement until the newest research data when this research was conducted. Based on the research background, it tries to examine the research with the title "The Influence of Firm Size, Audit Firm Size, Profitability, Solvability, and Public Ownership toward Audit Delay (An Empirical Study on Transportation Firms that Listed in IDX of 2008-2015)".

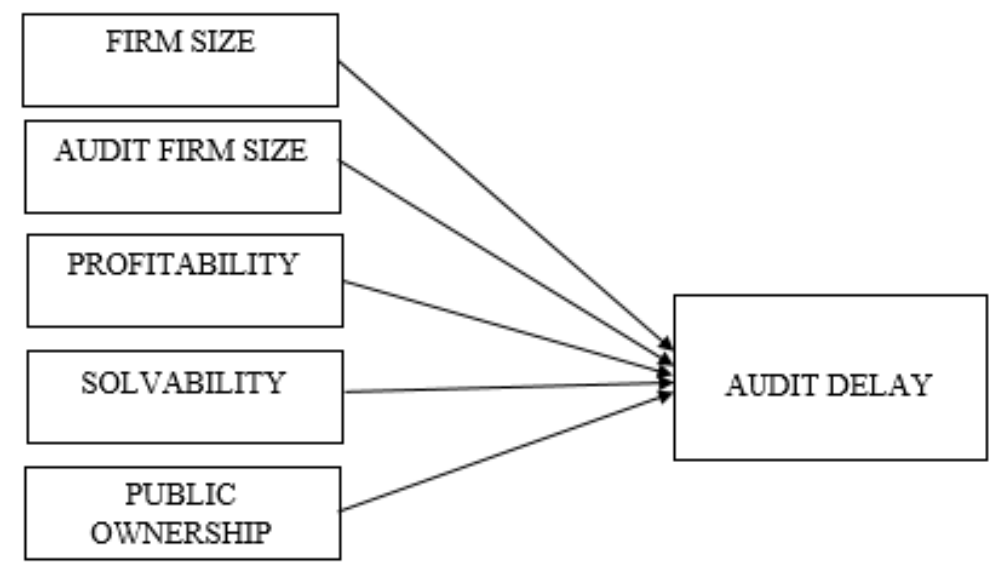

Figure 1. Conceptual Framework

\section{METHOD}

This research is empirical study with a quantitative approach. Quantitative research is a useful inquiry approach for describing trends and explaining relationships among variables. This study uses explanatory methods that identify causal relationships and perform comparisons (Kuncoro, 2003). The objects of this research are Firm size (X1) 
measured with total asset, audit Firm Size (X2) with dummy variable 1 for "big four" audit firm and 0 for "non-big four" audit firm, Profitability (X3) measured with ROA, Solvability (X4) measured with SOLV ratio that is total dept equity divided by total equity, Public Ownership (X5) measured with a percentage of shares as independent variables and audit delay (Y) as a dependent variable.

There are 33 firms of total firms listed on. The financial statement of a firm of transportation sector listed on the IDX in 2008-2015 period was used in this research population. The total population in this research is thirty three (33) firms. Based on the selection criteria of sample with purposive sampling, the number of sample of this study is 51. The analysis techniques used in this study are descriptive statistics, classical assumption test that include test of normality, multicollinearity, heteroscedasticity, and autocorrelation. To test hyphotical statements, this research also held hypothesis test that include test of multiple linear regression, simultaneous and partial. Meanwhile SPSS 16.0 application was used in this study to process the data.

Table 1. Analysis of Descriptive Statistics

\begin{tabular}{cllllll}
\hline Number & Variable & N & Min. & Max. & Mean & Std.Deviation \\
\hline 1. & Audit Delay $(\mathrm{Y})$ & 51 & 65.00 & 119.00 & 86.3922 & 11.200014 \\
2. & Firm Size $\left(\mathrm{X}_{1}\right)$ & 51 & 20.15 & 29.62 & 25.88894 & 3.16147 \\
3. & Audit Firm Size $\left(\mathrm{X}_{2}\right)$ & 51 & .00 & 1.00 & .4118 & .49705 \\
4. & Profitability $\left(\mathrm{X}_{3}\right)$ & 51 & -.49 & .45 & -.0508 & .16614 \\
5. & Solvability $\left(\mathrm{X}_{4}\right)$ & 51 & -1.78 & 6.11 & 1.7038 & 1.69699 \\
6. & Public Ownership $\left(\mathrm{X}_{5}\right)$ & 51.10 & .64 & .2490 & .11790 \\
\hline
\end{tabular}

\section{FINDING AND DISCUSSION}

\section{Descriptive Statistics}

Descriptive statistics functions as data analysis by explaining collected things without the purpose of making conclusion for generalization. Descriptive statistics is used to give description of variable data comprising of total of data, minimum and maximum value, mean, and standard deviation (Ghozali, 2005). Description of the descriptive statistical analysis was obtained by using SPSS 16.0. Descriptive statistical test results can be seen in table 1.

\section{Classical Assumption Test}

Classical assumption test has a purpose to assess the data condition of research. Moreover, it is used to choose the fit analysis of research model. This test is related to multiple regression method. Clasical Assumption include test of normality, multicollinearity, heteroscedasticity, and auto correlation criterion of those test follow (Suliyanto, 2011).

Based on the result of normality test with Kolmogorov Smirnov test, the $Z$ value is 0.450 with significance of 0.987 . It shows that the significance value is larger than alpha ( $\alpha$ 
$=0.05)$. It can be concluded that the residual value is normally distributed and the data can be processed for the next analysis. The result of multicollinearity test which uses VIF method in this research shows value $<10$. It can be concluded from the result that multicollinearity does not occur between independent variables. From the result of heteroscedasticity test it is seen that all independent variables have significance value $\geq$ 0.05 . This shows that heteroscedasticity does not occur in this reseach. Autocorrelation test is a test to examine the influence of residual variable on each of independent variable. This research uses autocorrelation test of Durbin Watson. This calculation get $d$ value (Durbin Watson) 1.540. As a result, it can fulfill the requirement of free from autocorrelation $\mathrm{dU}<\mathrm{d}<4$-dU $(1.3431<1.847<2.229)$.

\section{Goodness Fit Model}

\section{Simultaneous Test (F-Test)}

$F$-test is used to assess whether there is simultaneous influence on the independent variables toward the dependent variable. The criteria of testing is used if the probability value ( $p$-value) is $<0.05$. As a result $\mathrm{Ha}$ is supported. If the $p$-value is $>0.05$, as the result $H$ is not supported. $F$ test also can apply $F$-count and $F$-table comparably. If $F$-count is $>$ $F$-table $(n-h-1)$, as the result, Ha is supported. If $F$-count is $<F$-table $(n-k-1)$, as a result, $\mathrm{Ha}$ is not supported. Based on the results of multiple regression analysis in Table 4.8, the value of $\mathrm{F}$ arithmetic was 6.039 with a significance value of $0.000(0 \%)$. This is less than the $0.05(0 \%)$ significance level, so that it can be concluded that firm size, KAP size, profitability, solvency and public ownership affect audit delay. It means that the statistic data can reveal that all of independent variables $\left(\mathrm{X}_{1}, \mathrm{X}_{2}, \mathrm{X}_{3}, \mathrm{X}_{4}\right.$, and $\left.\mathrm{X}_{5}\right)$ have an effect to influence dependent variable $(\mathrm{Y})$. In other words, the independent variables used in this study have simultaneous effect on the dependent variable.

\section{Coefficient of Determination (Adjusted $R^{2}$ )}

The coefficient of determination test aims to determine the level of close relationship between independent and dependent variables. The better model is when the value of R2 is between zero and one, with a higher value again. The adjusted value of R2 shows the higher the relationship of the dependent variable to the independent variable. The results of this test were collected from multiple regression analysis (appendix 5). From that result, the adjusted $\mathrm{R} 2$ value is 0.335 . It means about $33.5 \%$ audit delay can be explained by research model influenced by independent variable equal to $33,5 \%$. $\mathrm{R}$ value of 0.634 indicates that the correlation coefficient in this study is $63.4 \%$.

\section{Multiple Linear Regression Analysis}

Multiple linear regression has a purpose to analyze relationship that occurs between independent and dependent variables. Moreover, it can find out the estimation or prediction of value from each independent variable toward dependent variable if a certain condition occurs. The meaning of condition is that up and down of the value of each independent variable is indicated on regression model (Suliyanto, 2011). Based on regression result, it can be formulated as follows: 


$$
\mathrm{Y}=109.980-0.662 \mathrm{X}_{1}-1.233 \mathrm{X}_{2}-30.938 \mathrm{X}_{3}-0.271 \mathrm{X}_{4}-28.368 \mathrm{X}_{5}+\mathrm{e}
$$

\section{Hypothesis Test}

\section{Partial Test (t-Test)}

Partial Test ( $t$-Test) is used to determine the influence of dependent variable and independent variable separately (Ghozali, 2005). The influence among them can be determined by statistically significance of 0.05 . The criteria of supported hypothesis is sig. $<0,05 t$ count $>t$ table, coeffisient $\beta$-, as a result, the hypothesis is supported. Meanwhile, if sig. $>0,05 t$ count $<t$ table, coeffisient $\beta+$, as a result, the hypothesis is not supported. The result and discussion of each independent variable is as follows (Can be seen in appendix 5):

\section{Hypothesis 1}

It can be seen that $t$ count for variable of firm size is $-0.662>t$ table $(-2.014)$ and probability value is $0.135>0.05$. It shows that firm size has an effect toward audit delay. As a result, it can be concluded that second hypothesis (H1) is supported.

\section{Hypothesis 2}

It can be seen that $t$ count for variable of audit firm size is $-1.233>\mathrm{t}$ table $(-2.014)$ and probability value is $0.649>0.05$. It shows that audit firm size has an effect toward audit delay. As a result, it can be concluded that second hypothesis (H2) is supported.

\section{Hypothesis 3}

It can be seen that $t$ count for variable of profitability is $-30.938<t$ table $(-2.014)$ and probability value is $0.000<0.05$. It shows that profitability has no effect toward audit delay. As a result, it can be concluded that third hypothesis (H3) is not supported.

\section{Hypothesis 4}

It can be seen that $t$ count for variable of solvability is $-0.271>t$ table $(-2.014)$ and probability value is $0.729>0.05$. It shows that solvability has no effect on audit delay. As a result, it can be concluded that second hypothesis (H4) is supported.

\section{Hypothesis 5}

It can be seen that $t$ count for variable of public ownership is $-28.368<\mathrm{t}$ table $(-2.014)$ and probability value is $0.019<0.05$. It shows that profitability has no effect on audit delay. As a result, it can be concluded that third hypothesis (H5) is not supported.

\section{Discussion}

\section{The Effect of Firm Size toward Audit Delay}

Based on the hypothesis of test result, it shows that the size of the company affects audit delay. This result is consistent with the formulated hypothesis. This proves that audit delay is affected by firm size because a large firm will be more consistent on timeliness compared to a small firm (Dyer \& Hugh, 1975). The size of a firm can be seen from various viewpoints such as total employees, total assets or wealth, total sales, capital market value, etc. Besides, the regression equation shows that firm size variable affect audit delay variable in a negative direction. A firm size has a significant relationship to the effect on audit delay (Ervilah \& Fachriyah, 2015). It is in line with a result which explains 
that a larger company would make audit delay longer than the usual one because audit area would be greater too (Agatha, 2015) since the larger companies have subsidiaries that require wider audit procedures (Ervilah \& Fachriyah, 2015).

\section{The Effect of Audit Firm Size toward Audit Delay}

Based on the hypothesis of test result, it shows that audit firm size affects audit delay. This result is consistent with the formulated hypothesis. Regression equation shows that audit firm size effect audit delay in a negative direction. This means that bigger audit firms would take longer time to audit than smaller ones as their clients are usually large companies with professional demand and fast result. This proves that financial statement audited by big four KAP has more quality than non big four firm size. In line with Puspitasari and Sari (2012), the size of audit firms can be seen from the level of service quality that has an effect on the time range of audit completion. Audit firm size could be influential when time of audit finishing can be seen from the result of an audit firm's quality. Ervilah and Fachriyah (2015) also explain that quality of an auditor projected by audit firm size has a significant relationship effect on audit delay.

\section{The Effect of Profitability toward Audit Delay}

Based on the hypothesis test result, it shows that profitability doesn't affect audit delay. This result is not consistent with the formulated hypothesis. This result is in line with the study by Rachmawati (2008) mentioning that profitability doesn't have an effect on audit delay. The regression equation shows that profitability on audit delay has a negative direction. This means companies that have big profits will be slower in the publication of financial statements than companies that report losses. The bigger profitability can give a signal to attract attention of government so that they could obtain higher tax when showing great profitability. This result is contrast to Arifuddin, Hanafi, \& Usman (2017) that shows that the profitability of the company has a close relationship with the company's information about good news or bad news from the financial statements. A company will deliver report earnings more quickly to its shareholders if it has a great profitability.

\section{The Effect of Solvability toward Audit Delay}

Based on the hypothesis test result, it shows that solvency doesn't affect audit delay. This result isn't consistent with the formulated hypothesis at the beginning. Based on the regression equation, solvency has no effect on audit delay and has a negative direction. According to (Puspitasari \& Sari, 2012), an unsolvable firm is a firm which has total liabilities of more than total assets. The meaning of firm with high solvability ratio is a firm which has high financial risk. This risk gives a signal that a firm will most likely not be able to repay the liabilities. The high solvability of company also has a negative impact on the firm because it will delay the publication of financial statement. The reason is firms that have financial difficulties tend to publish their financial statements not on time. However, insignificant result of this study means that it doesn't matter whether the 
companies have high or low solvency. It would not affect audit delay. The ability of a company to resolve all its obligations does not have a late or incorrect influence on the company in the publication of its financial statements. This is because the auditor's job standards are set out in the SPAP stating that the implementation of audit procedures of either companies with large or small debts will not affect the process of financial statement audit completion (Saemargani, 2015).

\section{The Effect of Public Ownership toward Audit Delay}

The hypothesis test result shows that public ownership doesn't affect audit delay. These results are inconsistent with the hypothesis that has been formulated. Based on the regression equation, the effect of public ownership on audit delay has a negative direction. Public ownership is an external party that is less involved in the preparation of financial statement. The time required to prepare financial statements is more likely to be the ability of management and the company's financial condition (Badriyah et al., 2015). This result is also in line with Mualimah, Andini, \& Oemar (2015) stating that public ownership doesn't have a significant relationship with a firm's delay of audit.

\section{CONCLUSION}

Based on test results in this study, it can be concluded that firm size and audit firm size have a negative effect on audit delay. Since the larger companies have subsidiaries that require wider audit procedures, it can make audit delay longer if the size of the company to be audited is larger. Then, the companies that are audited by "big four" audit firms have longer time to submit audited financial statement because they are usually big companies that demand professional and fast result. on the other hand, profitability, solvability, and public ownership don't show strong effect on audit delay. Companies that have big profits will be slower in the publication of financial statements than companies that report losses. Then, solvability is a signal for investors of future risks. Meanwhile, public ownership tends to be less involved in the preparation of making financial statements.

In order to control factors that cause late audit publication, a company should work professionally and conduct a regular evaluation. The company must also improve the control system in order to provide financial statements with no misstatements so that the financial statements are considered relevant, reliable, and timely. For auditors, the result of this research is expected to give information about delay audit factors at the transportation company. From this result, the auditor can control the more dominant factor causing audit delay, so that the audit process can be done efficiently and effectively. Limitations of this research are that several data samples didn't report their financial statements in 2008-2015. This study has limited scope for transportation industry so that it couldn't be literally generalized. Several company samples are removed from the research. The further research can add different test approach or other hypothesis testing such as; path analysis, regression analysis with panel data, and analysis with moderating variables. 
Jurnal Economia, 17(2), October 2021, 162-174

\section{REFERENCES}

Aditya, N. A., \& Anisykurlillah, I. (2014). Faktor-Faktor yang Berpengaruh terhadap Audit Delay. Accounting Analysis Journal, 3(3). https://doi.org/10.15294/aaj.v3i3.4204

Agatha. (2015). Pengaruh Solvabilitas, Tingkat Profitabilitas, Ukuran Perusahaan, Struktur Kepemilikan Publik, Arus Kas Operasi, Reputasi Auditor terhadap Audit Delay (Studi Empiris pada Perusahaan Sektor Otomotif yang Terdaftar di BEI Periode 2007-2012. Jurnal Ilmiah Mahasiswa Akuntansi UNDAP, 1(1).

Al-Ghanem, W., \& Hegazy, M. (2011). An Empirical Analysis of Audit Delay and Empirical Timeliness of Corporate Financial Reporting in Kuwait. Eurasian Business Review, 1, 73-90. https://doi.org/10.14208/BF03353799

Alkhatib, K., \& Qais, M. (2012). Audit Reports Timeliness: Empirical Evidence From Jordan. Procedia Social and Behavioral Sciences, 62, 1342-1349. https://doi.org/10.1016/j.sbspro.2012.09.229

Angruningrum, S., \& Wirakusuma, M. G. (2013). Pengaruh Profitabilitas, Leverage, Kompleksitas Operasi, Reputasi KAP dan Komite Audit pada Audit Delay. E-Jurnal Akuntansi UNUD, 5(2), 251-270.

Apriayanti, S. S., \& Santosa, S. (2014). Pengaruh dan Faktor Audit terhadap Keterlambatan Audit ada Perusahaan yang Terdaftar di Bursa Efek Malaysia. Jurnal Akuntansi Dan Keuangan, 16(2), 74-87. https://doi.org/10.9744/jak.16.2.74-87

Arifuddin, Hanafi, K., \& Usman, A. (2017). Company Size, Profitability, and Auditor Opinion Influence to AuditReport Lag on Registered Manufacturing Company in Indonesia Stock Exchange. International Journal of Applied Business and Economic Research, 15(19), 353-367. Retrieved from researchgate.net/publication/ 321299587_Company_Size_Profitability_and_Auditor_Opinion_Influence_to_Audit _Report_Lag_on_Registered_Manufacturing_Company_in_Indonesia_Stock_Exchan ge

Ayuningtyas, D. (2019). Perhatian! 24 Emiten Ini Kena Sanksi BEI, Kenapa? Retrieved August 2, 2020, from CNBC Indonesia website: https://www.cnbcindonesia.com/ marke/20190509090006-17-71388/perhatian-24-emiten-ini-kena-sanksi-bei-kenapa

Badriyah, S., Raharjo, K., \& Andini, R. (2015). Pengaruh Size, Solvabilitas, Kualitas Audit, Laba Rugi, Opini Audit dan Kepemilikan Publik terhadap Audit Delay pada Perusahaan Automotif di Bursa Efek Jakarta Tahun 2008-2013. Jurnal Ilmiah $U N P A D, 1(1)$.

Dabor, A. O., \& Mohammed, F. (2015). Determinants of Audit Delay in Banking Sector. Fountain Journal of Management and Social Sciences, 4(1), 74-91.

Divianto. (2011). Faktor-Faktor yang Berpengaruh terhadap Audit Delay Perusahaan Sektor Perdagangan yang Terdaftar di BEI Periode 2007-2009. Bandar Lampung University.

Dyer, J. C., \& Hugh, A. J. M. (1975). The Timeliness of the Australian Annual Report. Journal of Accounting Research, Autumn, 204-219. https://doi.org/10.2307/2490361 
Eisenhardt, K. (1989). Agency Theory: An Assesment and Review. Academy of Management Review, (14), 57-74. https://doi.org/10.2307/258191

Ervilah, \& Fachriyah, N. (2015). Faktor-Faktor yang Memengaruhi Audit Delay. Jurnal Mahasiswa FEB Universitas Brawijaya, 3(1).

Fitria, Y. G., Purnamasari, P., \& Utomo, H. (2015). Analisis Faktor-Faktor yang Memengaruhi Audit Delay pada Perusahaan dalam Indeks LQ 45 yang Terdaftar di Bursa Efek Indonesia (BEI) Periode 2010-2013. Prosiding Penelitian SPeSIA, 313-322. https://doi.org/10.29313/.v0i0.765

Ghozali, I. (2005). Aplikasi Analisis Multivarate dengan Program SPSS. Semarang: Badan Penerbit Universitas Diponegoro.

Haryani, J., \& Wiratmaja, I. . D. N. (2014). Pengaruh Ukuran Perusahaan, Komite Audit, Penerapan IFRS dan Kepemilikan Publik pada Audit Delay. E-Jurnal UNUD, 6(1), 63-78.

Hashim, U. J. B., \& Rahman, R. B. A. (2011). Audit Report Lag and the Effectiveness of Audit Committee. International Bulletin of Business Administration, (10).

Hasniar, F. (2012). Faktor-Faktor yang Memengaruhi Ketepatan Waktu Penyampaian Laporan Keuangan Studi Empiris pada Perusahaan Industri Barang Konsumsi yang Terdaftar di BEI Periode 2007-2011. Gunadarma University.

Hernawati, C., \& Rahayu, S. (2014). Pengaruh Ukuran Perusahaan, Tingkat Leverage dan Kualitas Kantor Akuntan Publik terhadap Audit Delay pada Perusahaan Sektor Transportasi yang Terdaftar di BEI Periode 2008-2012. Jurnal Eproc Telkom University, $1(3)$.

Hersugondo, \& Kartika, A. (2013). Prediksi Audit Delay dan Faktor Determinannya. Jurnal Ekonomi Manajemen Akuntansi, 20(35).

Ikatan Akuntansi Indonesia (IAI). (2007). Standar Akuntansi Keuangan (Second). Jakarta: Salemba Empat. Retrieved from https://www.google.co.id/search?hl=id\&tbo=p\&tb $\mathrm{m}=$ bks\&q=isbn:9796914344

Indonesia Stock Exchange. Retrieved October 1, 2016, from http://www.idx.co.id/

Jensen, M., \& Meckling, W. (1976). Theory of the Firm: Managerial Behavior, Agency Costs and Ownership Structure. Journal of Financial Economics, 3(4), 305-360. https://doi.org/10.1016/0304-405X(76)90026-X

Kuncoro, M. (2003). Metode Riset untuk Bisnis \& Ekonomi. Jakarta: Penerbit Erlangga.

Mualimah, S., Andini, R., \& Oemar, A. (2015). Pengaruh Ukuran Perusahaan, Komite Audit, Penerapan International Financial Reporting Standars (IFRS), Kepemilikan Publik Dan Solvabilitas Pada Audit Delay. Journal Of Accounting, 1(1).

Mulyadi. (2012). Auditing. Jakarta: Salemba Empat.

Otoritas Jasa Keuangan. Retrieved January 15, 2016, from http://www.ojk.go.id/ 
Puspitasari, E., \& Sari, A. . (2012). Pengaruh Karakteristik Perusahaan terhadap Lamanya Waktu Penyelesaian Audit (Audit Delay) pada Perusahaan Manufaktur yang Terdaftar di Bursa Efek Indonesia. Jurnal Akuntansi \& Auditing, 9(1), 1-96. https://doi.org/10.14710/jaa.9.1.31-42

Rachmawati, S. (2008). Pengaruh Faktor Internal dan Eksternal Perusahaan terhadap Audit Delay dan Timeliness. Jurnal Akuntansi Dan Keuangan, 10(1), 1-10. https://doi.org/10.9744/jak.10.1.PP.\%201-10

Rochmah, I. A., \& Fachriyah, N. (2016). Faktor-Faktor yang Memengaruhi Audit Delay (Studi Empiris pada Perusahaan Perbankan yang Terdaftar Di BEI Tahun 20102013). Jurnal Mahasiswa FEB Universitas Brawijaya, 3(2).

Ross, S. A. (1977). The Determination Of Financial Structure: The Incentive-Signaling Approach. The Bell Journal Of Economics, 8(1), 23-40. https://doi.org/10.2307/ 3003485

Saemargani, F. I. (2015). Pengaruh Ukuran Perusahaan, Umur Perusahaan, Profitabilitas, Solvabilitas, Ukuran KAP dan Opini Auditor terhadap Audit Delay. Nominal, Barometer Riset Akuntansi Dan Manajemen, 4(2), 1-15. https://doi.org/10.21831/ nominal.v4i2.7996

Sahamok. Retrieved January 16, 2016, from http://www.sahamok.com/

Suliyanto. (2011). Ekonometrika Terapan: Teori \& Aplikasi dengan SPSS. Yogyakarta: Andi.

Turel, A. (2010). Timeliness of Financial Reporting in Emerging Capital Markets: Evidence from Turkey. Instanbul University Journal of the School of Business Administration, 39(2), 227-240.

Vuko, T., \& Marko, C. (2014). Finding Determinants of Audit Delay by Pooled OLS Regression Analysis. Kroasian Operational Research, 5, 81-91. 